\title{
PEMANFAATAN MEDIA VISUAL DALAM MENULIS CERITA PENDEK PADA SEMESTER V PROGRAM STUDI PENDIDIKAN BAHASA INDONESIA FKIP UMSU
}

\author{
OKTAVIA LESTARI P \\ Universitas Muhammadiyah Sumatera Utara \\ oktavialestari@umsu.ac.id
}

\begin{abstract}
ABSTRAK
Pemanfaatan Media Visual bertujuan sebagai alat bantu dalam membantu mahasiswa menulis cerpen (cerita pendek). Disisi lain media visual juga dapat memudahkan mahasiswa dalam menemukan inspirasi atau gambaran untuk tokoh-tokoh yang akan mereka ciptakan dalam cerpen, serta membuat mahasiswa lebih percaya diri atas cerita yang mereka ciptakan, sehingga cerpen yang ditulis menjadi lebih menarik. Jika dikaitkan dengan menulis, maka dapat dinyatakan bahwa pemanfaatan media visual merupakan sebuah proses yang memudahkan mahasiswa untuk menemukan inspirasi dalam menulis cerpen. Jadi, pemanfaatan media visual dapat digunakan dalam setiap proses pembelajaran, terutama ketika nantinya mahasiswa akan menjadi seorang guru bisa mempraktikkan dengan siswa-siswi di sekolah. Penelitian ini bertujuan untuk mengetahui pemanfaatan media visual dalam proses menulis cerpen pada mahasiswa semester $V$ pada Prodi Pendidikan Bahasa dan Sastra Indonesia FKIP UMSU dengan menggunakan metode eksperimen. Berdasarkan hasil penelitian yang diperoleh yang telah dijabarkan pada bab sebelumnya, dapat dikatakan pemanfaatan media visual pada mahasiswa Semester V FKIP UMSU berada pada kategori baik di mana nilai rata-rata siswa 83,84.
\end{abstract}

Kata kunci: media visual, menulis, dan cerpen

\section{PENDAHULUAN}

Upaya mengembangkan pendidikan merupakan tanggung jawab seorang dosen terhadap mengembangkan kemampuan mahasiswa dalam menggunakan media visual alat bantu dalam proses perkuliahan.
Media visual berperan penting dalam menentukan berhasil tidaknya peserta dalam kegiatan belajar mengajar. Oleh karena itu, strategi perkuliahan disesuaikan 
dengan perkembangan ilmu pengetahuan dan teknologi yang disertai arus globalisasi.

Trianto (2011:5) berpendapat bahwa "masalah utama dalam pembelajaran pada pendidikan formal (sekolah) dewasa ini adalah masih rendahnya daya serap peserta didik". Pengajaran dengan sistem belajar tradisional yakni dosen lebih mendominasi seluruh kegiatan pembelajaran sedangkan mahasiswa hanya menerima perkuliahan secara pasif akan mengakibatkan mahasiswa kurang mandiri.

\section{A. Kajian Teori}

\section{Pengertian Media Visual}

Media merupakan salah satu faktor penentu keberhasilan pembelajaran. Melalui media, proses pembelajaran bisa lebih menarik dan menyenangkan, misalnya mahasiswa yang memiliki ketertarikan terhadap warna dapat diberikan media dengan warna yang menarik, begitu juga dengan mediamedia yang lainnya. Sama juga dengan media teknologi, seperti halnya komputer yang banyak berisi tentang pembelajaran yang dikemas sangat menyenangkan buat mahasiswa, sehingga mahasiswa sangat tertarik dengan belajar melalui media. Aspek penting lainnya, penggunaan media dapat membantu memperjelas pesan pembelajaran.

Media pendidikan membantu segala sesuatu yang dapat digunakan dosen untuk mencapai tujuan. Secara metodologis media pendidikan bertujuan:

1) Membantu memperjelas pokok bahasan yang disampaikan dosen

2) Membantu memotivasi peserta didik dalam kegiatan pembelajaran
3) Membantu para dosen mengatasi ruang tempat dan waktu

4) Memberi pengalaman nyata kepada peserta didik.

Menurut Arsyad media berbasis visual (image atau perumpamaan) memegang peranan yang sangat penting dalam proses pmbelajaran. Media visual dapat memperlancar pemahaman dan memperkuat ingatan. Visual dapat pula menumbuhkan minat siswa serta dapat memberikan hubungan antara isi materi pelajaran dengan dunia nyata. Agar menjadi efektif, visual sebaiknya ditempatkan pada konteks yang bermakna dan siswa harus berinteraksi dengan visual (image) itu untuk meyakinkan terjadinya proses informasi.

\section{Media Pembelajaran Visual}

Menurut Gearlah bahwa media apabila difahami secara umum media itu meliputi orang, bahan, peralatan, atau kegiatan yang menciptakan kondisi yang memungkinkan siswa memperoleh pengetahuan, keterampilan atau sikap. Pembelajaran adalah proses interaksi antara peserta didik dengan lingkungannya, sehingga terjadi perubahan perilaku ke arah yang lebih baik. Dalam mendefinisikan media pembelajaran tardapat beberapa pendapat para ahli di antaranya yaitu: a) Briggs dalam buku Yusuf Hadi Miarso menyatakan bahwa media pembelajaran adalah sarana untuk memberikan perangsang bagi si belajar supaya proses belajar terjadi. b) Menurut Suwarno Pringgawidagda media pembelajaran adalah alat yang dipakai sebagai saluran menyampaikan materi pelajaran kepada pembelajar. 


\section{Fungsi Media Pembelajaran Visual}

Levie dan Lentz (1982) dalam bukunya Azhar Arsyad mengemukakan 4 fungsi media pembelajaran visual, yaitu Fungsi atensi, Fungsi afektif, Fungsi kognitif, dan Fungsi kompensatoris. Fungsi Atensi merupakan inti yaitu menarik dan mengarahkan perhatian siswa untuk berkonsentrasi kepada isi pelajaran yang berkaitan dengan makna visual yang ditampilkan atau menyertai teks materi pengajaran. Sering kali pada awal pelajaran siswa tidak tertarik dengan materi pelajaran karena itu merupakan pelajaran yang tidak disenangi oleh mereka sehingga mereka tidak memperhatikan. Media gambar yang diproyeksikan dapat menenangkan dan mengarahkan perhatian mereka kepada pelajaran yang akan mereka terima. Dengan demikian untuk memperoleh dan mengingat isi pelajaran semakin besar.

Fungsi Afektif, media visual dapat terlihat dari tingkat kenikmatan siswa ketika belajar (membaca) teks yang bergambar. Gambar atau lambang visual dapat menggugah emosi dan sikap siswa.

Fungsi Kognitif, media visual terlihat dari temuan-temuan penelitian yang mengungkapkan bahwa lambang visual dapat memperlancar pencapaian tujuan untuk memahami dan mengingat informasi atau pesan yang terkandung dalam gambar. Fungsi Kompensatoris, media pembelajaran visual terlihat dari hasil penelitian bahwa media visual yang memberikan konteks untuk memahami teks membantu siswa yang lemah dalam membaca untuk mengorganisasikan informasi dalam teks dan mengingatnya kembali. Dengan kata lain, media pembelajaran berfungsi untuk mengakomodasikan siswa yang lambat menerima dan memahami isi pelajaran yang disajikan dengan teks atau secara verbal.

\section{Manfaat Media Pembelajaran Visual}

Media pembelajaran dapat mempertinggi proses belajar mahasiswa dalam pengajaran yang pada gilirannya diharapkan dapat mempertinggi hasil belajar yang dicapainya. Ada beberapa alasan, mengapa media pembelajaran dapat mempertinggi proses belajar mahasiswa? Salah satu alasan tersebut berkenaan dengan manfaat media pembelajaran dalam proses belajar mahasiswa, antara lain: a) Proses pembelajaran akan lebih menarik perhatian mahasiswa b) Bahan pengajaran akan lebih mudah difahami oleh mahasiswa c) Metode pembelajaran akan lebih bervariasi. Dengan media proses pembelajaran tidak akan bersifat verbalistik d) mahasiswa akan dapat melakukan aktivitas, karena mahasiswa tidak hanya mendengarkan tetapi juga dapat mengamati, mendemonstrasikan, memerankan, dan lainlain.

\section{Pengertian Menulis}

Menulis merupakan salah satu keterampilan berbahasa yang sangat dibutuhkan pada masa sekarang. Keterampilan menulis tidak mudah dimiliki dan memerlukan waktu yang lama untuk memperolehnya. Dengan menulis seseorang dapat mengekspresikan ide-ide atau gagasannya melalui bahasa tulis.

Tarigan (2005: 21) menyatakan "Menulis adalah menurunkan atau melukiskan lambang-lambang grafik yang menggambarkan suatu bahasa yang dipahami oleh seseorang sehingga orang lain dapat membaca lambang-lambang grafik tersebut kalau mereka memahami bahasa grafik itu". 
Widyamartaya (2002: 5) menyatakan bahwa mengarang atau menulis adalah kegiatan yang kompleks. Mengarang dapat kita pahami sebagai suatu rangkaian kegiatan seseorang mengungkakan gagasan dan menyampaikannya melalui bahasa tulis kepada pembaca untuk dipahami tepat seperti yang dimasudkan pengarang.

\section{a. Pengertian Cerita Pendek}

Dalam sastra dikenal dengan tiga macam bentuk, yaitu puisi, prosa, dan drama. Bentuk prosa terdiri dari bermacammacam jenis, salah satu prosa adalah cerpen. Sesuai dengan namanya cerpen adalah cerita pendek, tetapi panjang pendek ukuran fisiknya tidak jadi ukuran mutlak. Tidak ditentukan cerpen harus sekian halaman atau sekian kata, walaupun cerpen mempunyai kecenderungan untuk berukuran pendek.

Menurut Kamus Besar Bahasa Indonesia (Depdiknas 2007: 210), “Cerita pendek adalah kisahan pendek (kurang dari 10.000 kata) yang memberikan kesan tunggal yang dominan, dan memusatkan diri pada satu tokoh di satu situasi”. Sedangkan menurut A. Bakar Hamid (dalam Soebachman, 2014: 68) mengatakan bahwa yang disebut cerita pendek itu harus dilihat dari kuantitas, yaitu banyaknya perkataan yang dipakai: antara 500-20.000 kata; adanya satu plot; adanya satu watak; dan adanya satu kesan.

Sementara itu Kosasih (2003: 391) mengatakan "Cerpen adalah cerita yang menurut wujud fisiknya berbentuk pendek. Ukuran panjang pendeknya suatu cerita memang relatif. Cerita pendek merupakan cerita yang habis dibaca sekitar sepuluh menit atau setengah jam. Jumlah katanya sekitar 500-5000 kata. Karena itu, cerita pendek sering diungkapkan dengan cerita yang dapat dibaca sekali duduk.

\section{Ciri-ciri Cerita Pendek}

Adapun ciri-ciri sebuah cerita pendek adalah sebagai berikut:

1. Bentuk tulisan singkat, padat, dan lebih pendek daripada novel.

2. Tulisan kurang dari 10.000 kata.

3. Sumber cerita dari kehidupan sehari-hari, baik pengalaman sendiri maupun orang lain.

4. Tidak melukiskan seluruh kehidupan pelakunya karena mengangkat masalah tunggal atau sarinya saja.

5. Habis dibaca sekali duduk dan hanya mengisahkan sesuatu yang berarti bagi pelakunya.

6. Tokoh-tokohnya dilukiskan mengalami konflik sampai pada penyelesaiannya.

7. Penggunaan kata-katanya sangat ekonomois dan mudah dikenal masyarakat.

8. Meninggalkan kesan mendalam dan efek pada perasaan pembaca.

9. Menceritakan satu kejadian dari terjadinya perkembangan jiwa dan krisis, tetapi tidak sampai menimbulkan perubahan nasib.

10. Beralur tunggal dan lurus.

\section{METODE PENELITIAN}

Penelitian ini dilakukan pada mahasiswa semester VI Prodi Pendidikan Bahasa dan Sastra Indonesia FKIP UMSU. Jenis penelitian ini adalah penelitian eksperimen. Populasi dari penelitian ini ada 2 kelas prodi pendidikan bahasa dan sastra Indonesia semerter VI. Yang berjumlah lebih kurang 68 orang mahasiswa Pendidikan Bahasa dan Sastra Indonesia 
Fakultas Keguruan dan Ilmu Pendidikan Universitas Muhammadiyah Sumatera Utara tahun ajaran 2018/2019.

\section{Teknik Pengumpulan Data}

Adapun instrumen penelitian ini adalah berupa eksperimen dan kontrol (post test dan pre test) yang diberikan kepada mahasiswa dan juga peneliti melakukan pengamatan selama berlangsung proses pembelajaran.

\section{Teknik Analisis Data}

1. Uji prasyaratan : uji normalitas

2. Uji hipotesis : untuk melihat upaya pengembangan materi ajar berbasis media pembelajaran dalam meningkatkan motivasi belajar.

\section{Uji Normalitas Data}

Salah satu persyaratan analisis yang harus dipenuhi agar dapat menggunakan statistik parametrik adalah sebaran data setiap variabel penelitian harus berdistribusi normal. Pengujian normal tidaknya sebaran data dapat dilakukan dengan menggunakan uji Liliefors.

Tabel 1

Uji Normalitas Data Kelompok Media Visual

\begin{tabular}{|c|c|c|c|c|c|c|c|c|}
\hline $\begin{array}{l}\mathrm{N} \\
\mathrm{O}\end{array}$ & $\begin{array}{l}X \\
1\end{array}$ & $\mathrm{~F}$ & $\begin{array}{l}\mathrm{F}_{\mathrm{ku}} \\
\mathrm{m}\end{array}$ & $\mathrm{Zi}$ & $\mathrm{Zi}_{\mathrm{tab}}$ & $\begin{array}{l}\mathrm{F}(\mathrm{Zi} \\
)\end{array}$ & $\begin{array}{l}\mathrm{S}(\mathrm{Zi} \\
)\end{array}$ & $\begin{array}{l}\mathrm{L}=\mathrm{F}(\mathrm{Z} \\
\mathrm{i})- \\
\mathrm{S}(\mathrm{Zi})\end{array}$ \\
\hline 1 & $\begin{array}{l}7 \\
1\end{array}$ & 4 & 4 & \begin{tabular}{|l}
- \\
1,7 \\
8
\end{tabular} & $\begin{array}{l}- \\
0,46 \\
25\end{array}$ & $\begin{array}{l}0,03 \\
75\end{array}$ & $\begin{array}{l}0,10 \\
52\end{array}$ & $\begin{array}{l}0,067 \\
7\end{array}$ \\
\hline 2 & $\begin{array}{l}7 \\
6\end{array}$ & 6 & 10 & \begin{tabular}{|l}
- \\
1,0 \\
8 \\
\end{tabular} & $\begin{array}{l}- \\
0,35 \\
99\end{array}$ & $\begin{array}{l}0,14 \\
01\end{array}$ & $\begin{array}{l}0,26 \\
31\end{array}$ & 0,123 \\
\hline 3 & $\begin{array}{l}8 \\
1\end{array}$ & 8 & 18 & \begin{tabular}{|l}
- \\
0,3 \\
9
\end{tabular} & 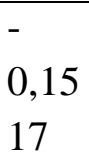 & $\begin{array}{l}0,34 \\
84\end{array}$ & $\begin{array}{l}0,47 \\
36\end{array}$ & $\begin{array}{l}0,125 \\
2\end{array}$ \\
\hline
\end{tabular}

\begin{tabular}{|l|l|l|l|l|l|l|l|l|}
\hline 4 & 8 & 3 & 21 & $\begin{array}{l}0,2 \\
9\end{array}$ & $\begin{array}{l}0,01 \\
41\end{array}$ & $\begin{array}{l}0,51 \\
41\end{array}$ & $\begin{array}{l}0,55 \\
26\end{array}$ & $\begin{array}{l}0,038 \\
5\end{array}$ \\
\hline 5 & 9 & 1 & 36 & $\begin{array}{l}0,8 \\
5\end{array}$ & $\begin{array}{l}0,31 \\
23\end{array}$ & $\begin{array}{l}0,81 \\
23\end{array}$ & $\begin{array}{l}0,94 \\
73\end{array}$ & $\mathbf{0 , 1 3 5}$ \\
\hline 6 & 9 & 5 & 2 & 38 & $\begin{array}{l}1,5 \\
4\end{array}$ & 0,43 & 0,93 & 1,00 \\
82 & 82 & 00 & $\begin{array}{l}0,061 \\
8\end{array}$ \\
\hline
\end{tabular}

Berdasarkan tabel di atas diperoleh harga $L_{\text {hitung }}=0,135$ sedangkan dari daftar nilai untuk uji Liliefors pada taraf signifikan $\alpha=0,05$ dan $\mathrm{n}=38$ adalah $\frac{0,886}{\sqrt{N}}=\frac{0,886}{\sqrt{38}}=\frac{0,886}{6,164}=0,1437$

Dengan demikian diperoleh $\mathrm{L}_{\text {hitung }}<$ $\mathrm{L}_{\text {tabel }}$ atau $0,135<0,1437$ yang berarti data nilai kelompok pembelajaran memanfaatkan media pembelajaran berdasarkan dari populasi yang berdistribusi normal. Pengujian normalitas data kelompok media visual di atas, perhitungannya sebagai berikut:

Diketahui:

$$
\bar{X}_{1}=83,84 ; \mathrm{SD}_{1}=7,21 ; \mathrm{N}=38
$$

\section{Tabel 2}

Uji Normalitas Data Tanpa Media Visual

\begin{tabular}{|c|c|c|c|c|c|c|c|c|}
\hline $\begin{array}{l}\mathrm{N} \\
\mathrm{o}\end{array}$ & $\begin{array}{l}\mathrm{X} \\
1\end{array}$ & $\mathrm{~F}$ & $\begin{array}{l}\mathrm{F}_{\mathrm{ku}} \\
\mathrm{m}\end{array}$ & $\mathrm{Zi}$ & $\mathrm{Zi}_{\mathrm{tab}}$ & $\mathrm{F}(\mathrm{Zi}$ & $\begin{array}{l}\mathrm{S}(\mathrm{Zi} \\
)\end{array}$ & $\begin{array}{l}\mathrm{L}=\mathrm{F}(\mathrm{Z} \\
\mathrm{i})- \\
\mathrm{S}(\mathrm{Zi})\end{array}$ \\
\hline 1 & $\begin{array}{l}5 \\
2\end{array}$ & 4 & 4 & \begin{tabular}{|l}
- \\
1,6 \\
5
\end{tabular} & $\begin{array}{l}- \\
0,45 \\
05\end{array}$ & $\begin{array}{l}0,04 \\
95\end{array}$ & $\begin{array}{l}0,13 \\
33\end{array}$ & $\begin{array}{l}0,083 \\
8\end{array}$ \\
\hline 2 & \begin{tabular}{|l|}
5 \\
7
\end{tabular} & 4 & 8 & $\begin{array}{l}- \\
0,9 \\
0\end{array}$ & $\begin{array}{l}- \\
0,31 \\
59\end{array}$ & $\begin{array}{l}0,18 \\
41\end{array}$ & $\begin{array}{l}0,26 \\
66\end{array}$ & $\begin{array}{l}0,082 \\
5\end{array}$ \\
\hline 3 & $\begin{array}{l}6 \\
2\end{array}$ & $\begin{array}{l}1 \\
0\end{array}$ & 18 & $\begin{array}{l}- \\
0,1 \\
5\end{array}$ & $\begin{array}{l}- \\
0,05 \\
96\end{array}$ & $\begin{array}{l}0,44 \\
04\end{array}$ & 0,6 & $\begin{array}{l}0,159 \\
6\end{array}$ \\
\hline 4 & $\begin{array}{l}6 \\
7\end{array}$ & 7 & 25 & $\begin{array}{l}0,6 \\
0\end{array}$ & $\begin{array}{l}0,22 \\
57\end{array}$ & $\begin{array}{l}0,72 \\
57\end{array}$ & $\begin{array}{l}0,83 \\
33\end{array}$ & $\begin{array}{l}0,107 \\
6\end{array}$ \\
\hline
\end{tabular}




\begin{tabular}{|c|c|c|c|c|c|c|c|c|}
\hline 5 & \begin{tabular}{|l|}
7 \\
1
\end{tabular} & 3 & 28 & $\begin{array}{l}1,2 \\
0\end{array}$ & $\begin{array}{l}0,38 \\
49\end{array}$ & $\begin{array}{l}0,88 \\
49\end{array}$ & $\begin{array}{l}0,93 \\
33\end{array}$ & $\begin{array}{l}0,048 \\
4\end{array}$ \\
\hline 6 & 7 & 2 & 30 & 1,9 & 0,47 & 0,97 & 1,00 & 0,025 \\
\hline & 6 & & & 5 & 44 & 44 & 00 & 6 \\
\hline
\end{tabular}

Berdasarkan tabel di atas diperoleh harga $\mathrm{L}_{\text {hitung }}=0,1596$ sedangkan dari daftar nilai untuk uji Liliefors pada taraf signifikan $\alpha=0,05$ dan $\mathrm{n}=30$ adalah 0,161

Dengan demikian diperoleh $\mathrm{L}_{\text {hitung }}<$ $\mathrm{L}_{\text {tabel }}$ atau $0,1596<0,161$ yang berarti data nilai kelompok pembelajaran tanpa memanfaatkan media visual berasal dari populasi yang berdistribusi normal. Pengujian normalitas data kelompok tanpa memanfaatkan media di atas, perhitungannya sebagai berikut:

Diketahui:

$$
\bar{X}_{2}=63 ; \mathrm{SD}_{2}=6,64 ; \mathrm{N}=30
$$

\section{HASIL DAN PEMBAHASAN}

Setelah diketahui bahwa untuk data hasil belajar kedua sampel berdistribusi normal dan homogen, selanjutnya dilakukan pengujian hipotesis. Nilai mahasiswa dapat dianalisis dengan menggunakan rumus uji $\mathrm{t}$ untuk dapat menguji hipotesis penelitian. Sebelum melakukan uji hipotesis, peneliti menyimpulkan kembali nilai yang diperoleh siswa pada kelas eksperimen maupun kelas kontrol. Daftar nilai kemampuan mahasiswa pada kelas eksperimen yang memanfaatkan media visual dan nilai kemampuan mahasiswa pada kelas kontrol yang tidak memafaatkan adalah sebagai berikut:

1. Untuk hasil belajar mahasiswa kelas eksperimen (dengan memanfaatkan media visual)

$\bar{X}_{1}=83,84 ; \quad \mathrm{SD}_{1}=7,21 ; \quad \mathrm{SD}_{1}^{2}=$ 51,$98 ; \mathrm{N}=38$
2. Untuk hasil belajar siswa kelas kontrol (tanpa media visual)

$\bar{X}_{1}=63 ; \mathrm{SD}_{2}=6,64 ; \mathrm{SD}_{2}^{2}=44,08 ;$ $\mathrm{N}=30$

$$
\mathrm{t}_{\text {hitung }}=\frac{\bar{X}_{1-} \bar{X}_{2}}{s \sqrt{\frac{1}{n_{1}}+\frac{1}{n_{2}}}}
$$

Dengan perhitungan $\mathrm{S}$ sebagai berikut:

$$
\begin{aligned}
S^{2} & =\frac{\left(n_{1}-1\right) S_{1}^{2}+\left(n_{2}-1\right) S_{2}^{2}}{\left(n_{1}+n_{2}\right)-2} \\
& =\frac{(38-1) 51,98+(30-1) 44,08}{(38+30)-2} \\
& =\frac{(37) 51,98+(29) 44,08}{68-2} \\
& =\frac{1923,26+1278,32}{66} \\
& =\frac{3201,58}{66} \\
S^{2} & =48,50 \\
S & =\sqrt{48,50} \\
S & =6,96
\end{aligned}
$$

Dengan demikian,

$$
\begin{aligned}
t_{\text {hitung }} & =\frac{\bar{X}_{1-} \bar{X}_{2}}{s \sqrt{\frac{1}{n_{1}}+\frac{1}{n_{2}}}} \\
& =\frac{83,84-63}{6,96 \sqrt{\frac{1}{n_{1}}+\frac{1}{n_{2}}}} \\
& =\frac{20,84}{6,96 \sqrt{\frac{1}{38}+\frac{1}{30}}} \\
& =\frac{20,84}{6,96 \sqrt{0,02+0,03}} \\
& =\frac{20,84}{6,96 \sqrt{0,05}} \\
& =\frac{20,84}{6,96(0,223)} \\
& =\frac{20,84}{1,55} \\
t_{\text {hitung }} & =13,44
\end{aligned}
$$

Dari daftar distribusi t untuk $\alpha=0,05$ dan $\mathrm{dk}=38+30-2=66$, diperoleh harga 
$\mathrm{t}_{\text {tabel }}=1,997$. Dengan membandingkan antara $t_{\text {hitung }}$ dengan $t_{\text {tabel }}$ diperoleh $t_{\text {hitung }}>$ $t_{\text {tabel }}$ atau $13,44>1,997$ sehingga $h_{a}$ diterima dan $h_{o}$ ditolak. Disimpulkan pemanfaatan media visual lebih efektif dibandingkan dengan tanpa pemanfaatan media visual dalam meningkatkan kemampuan menulis teks cerita pendek oleh mahasiswa semester V Program Studi Pendidikan Bahasa Dan Sastra Indoneisa UMSU. Dengan demikian hipotesis diperoleh terbukti kebenarannya.

Setelah ditentukan kelas eksperimen dan kelas kontrol kemudian kedua kelas diberi perlakuan, kelas eksperimen diberi perlakuan dengan memanfaatkan media visual dan kelas kontrol diberi perlakuan tanpa media visual.

Setelah diberi perlakuan yang berbeda pada kelas eksperimen dan kelas kontrol, kemudian kedua kelas diberikan postes atau teks akhir untuk mengetahui kemampuan akhir mahasiswa dari kelas eksperimen dan kelas kontrol..

Hasil penelitian menunjukkan bahwa nilai siswa pada kelas eksperimen dan kelas kontrol mengalami perbedaan yang cukup signifikan. Hal tersebut menunjukkan hasil pembelajaran memanfaatkan media visual sudah mencapai nilai maksimal atau memenuhi kriteria ketuntasan minimum dengan nilai rata-rata siswa 83,84. Sedangkan kelas kontrol tanpa media visual memperloleh nilai rata-rata siswa 63 . Kemudian dilakukan pengujian hipotesis untuk hasil belajar dengan mengunakan ujit. Setelah dilakukan pengujian data hasil belajar ternyata diperoleh hasil pengujian pada taraf $\alpha=0,05$ diperoleh $\mathrm{t}_{\text {hitung }}>\mathrm{t}_{\text {tabel }}$ yaitu 13,44 >1,997

Berdasarkan hasil hipotesis penelitian di atas dapat disimpulkan bahwa pembelajaran menulis teks cerita pendek dengan memanfaatkan media visual sangat disarankan terhadap mahasiswa karena mampu meningkatkan dan mempermudah mahasiswa dalam proses belajar mengajar, khususnya pada pembelajaran menulis teks cerita pendek.

\section{KESIMPULAN}

Penelitian ini bertujuan untuk mengetahui pemanfaatan media visual dalam proses pembelajaran menulis teks cerita pendek, maka dapat disimpulkan beberapa hal yang merupakan inti dari penelitian ini, yaitu:

1. Kemampuan menulis teks cerita pendek dengan memanfaatkan media visual pada kelas eksperimen mendapatkan hasil paling dominan baik, dapat dibuktikan dengan nilai 83,84 .

2. Kemampuan menulis teks cerita pendek tanpa media visual pada kelas kontrol mendapatkan hasil paling dominan kurang, dapat dibuktikan dengan nilai 63 .

3. Berdasarkan hal di atas dapat diambil kesimpulan bahwa pemanfaaatan media visual dapat meningkatkan kemampuan mahasiswa dalam menulis teks cerita pendek.

\section{REFERENSI}

Arikunto,S dkk. 2009. Dasar-Dasar Evaluasi Pendidikan. Jakarta: Bumi Aksara.

Asyhar, R. 2011. Kreatif Mengembangkan Media Pembelajaran. Jakarta: Gaung Persadan Press. 
Depdiknas. 1995. Kamus Besar Bahasa Indonesia. Jakarta: Balai Pustaka.

Dimiyati dan Mudjiono, 2010. Belajar dan Pembelajaran. Jakarta: Rineka Cipta.

Gulo. 2011. Strategi Belajar Mengajar. Jakarta: Grasindo.

Komunikasi Pendidik. Winarno. dkk. 2009. Teknik Evaluasi Multimedia Pembelajaran. Genius Prima Media.

Krismanto, dkk. 2003. Model Pembelajaran Inovatif. Jakarta : Prestasi pustaka.

Lie, Anita. 2000. Cooperative Learning Mempraktekkan Cooverative Learning di Ruang-ruang Kelas. Jakarta: Grasindo.

Munadi,Y. 2008. Media Pembelajaran Sebuah Pendekatan Baru. Jakarta: Gaung Persada Press.

Putra, M. S. 2006, Teknik Menulis Berita dan Feature. Jakarta: PT. Indeks.

Subana dan Sunarti. 2000. Strategi Belajar Mengajar Bahasa Indonesia. Bandung: Pustaka Setia.

Sudjana.2005. Metode Statistika. Bandung : Tarsino.

Sudjono, Anas. 2006. Pengantar Statistik Pendidikan. Jakarta: Raja Grafindo 